\title{
RESENSI \\ MENYELAMI ILMU BIOLOGI MOLEKULER DAN GENETIKA DARI BUKU GENOMES 3
}

\author{
Intan Ruspita \\ Fakultas Kedokteran Gigi Universitas Gadjah Mada
}

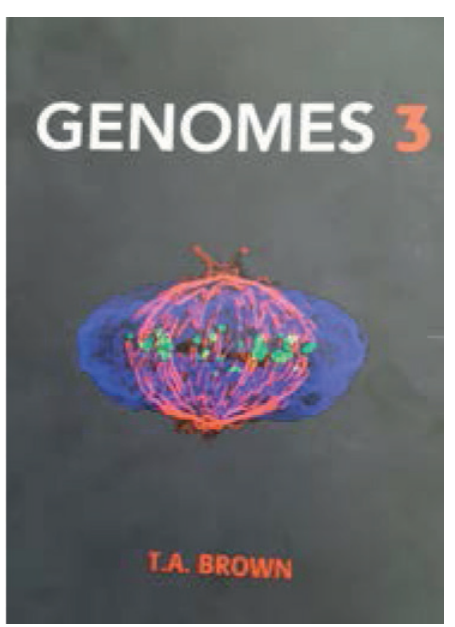

Dalam penyusunannya, buku ini dibagi dalam empat bagian, bagian pertama merupakan bab-bab perkenalan terhadap genome, tanscriptome dan proteotome serta proses transkripsi dan translasinya. Bagian kedua menjelaskan tentang anatomi genome dan berbagai tipe genome yang terdapat di alam. Bagian ketiga menjelaskan bagaimana fungsi genome, proses sintesis RNA, proteotome serta berbagai isu penting tentang struktur kromatin yang dapat mempengaruhi ekspresi genome. Bagian keempat menjelaskan secara detail bagaimana replikasi genome dan keterlibatannya pada replikasi DNA, mutasi DNA dan rekombinasi DNA. Setiap topik dalam buku ini dilengkapi dengan gambar berwarna, yang sangat membantu menuntun pembaca untuk lebih memahami topik yang
: Genomes 3

: TA Brown

: Garland Science, Taylor and Francis

: 2006

: 713 halaman

:0 815341385

Buku Genomes 3 merupakan buku yang sangat dianjurkan untuk dibaca oleh ilmuwan di era yang sangat pesat akan perkembangan ilmu pengetahuan dan teknologi, khususnya ilmu molekuler biologi dan genetika. Penulisan buku disusun dengan sangat hati hati agar mudah dipahami oleh pembaca dan dilengkapi dengan CD-ROM yang dapat dilihat dalam dua format, power point dan JPEG.

sedang dibahas. Disetiap akhir dari bab diberi latihan soal agar pembaca dapat menilai dan mengukur sejauh mana pengetahuan yang telah diperoleh dan dipahami sebelum melanjutkan pada bab berikutnya.

Meskipun buku ini ditulis dalam bahasa inggris, pembaca akan terbawa dengan jalan cerita yang disusun secara rapi, langkah demi langkah, sehingga dapat menjadi konsumsi kalangan mahasiswa sarjana dan pasca sarjana, serta ilmuwan lain pada bidang minat yang sesuai. Secara keseluruhan, memahami isi dari buku ini akan mempermudah pembaca dalam menyelami ilmu biologi molekuler dan genetika untuk diaplikasikan sesuai dengan perkembangan teknologi dan pengetahuan terkini. 